Abstracta Iranica Abstracta Iranica

Revue bibliographique pour le domaine irano-aryen

Volume 25 | 2004

Comptes rendus des publications de 2002

\title{
Los cinco tratados sobre la quietud (elyâ) de Dâdîsh "' Qaflrâyâ. (= Aula Orientalis. Supplementa 18), Bercelone, 2001, 174 p., biblio., index.
}

\section{Florence Jullien}

\section{(2) OpenEdition}

1 Journals

\section{Édition électronique}

URL : http://journals.openedition.org/abstractairanica/4814

DOI : 10.4000/abstractairanica.4814

ISSN : 1961-960X

Éditeur :

CNRS (UMR 7528 Mondes iraniens et indiens), Éditions de l'IFRI

\section{Édition imprimée}

Date de publication : 15 mai 2004

ISSN : 0240-8910

Référence électronique

Florence Jullien, "Los cinco tratados sobre la quietud (elyâ) de Dâdîsh"“' Qaflrâyâ. (= Aula Orientalis. Supplementa 18), Bercelone, 2001, 174 p., biblio., index. », Abstracta Iranica [En ligne], Volume 25 | 2004, document 225, mis en ligne le 15 mars 2006, consulté le 25 septembre 2020. URL : http:// journals.openedition.org/abstractairanica/4814 ; DOI : https://doi.org/10.4000/abstractairanica.4814

Ce document a été généré automatiquement le 25 septembre 2020.

Tous droits réservés 
Los cinco tratados sobre la quietud (elyâ) de Dâdîish"' Qaflrâyâ. (= Aula Orientalis. Supplementa 18), Bercelone, 2001, 174 p., biblio., index.

Florence Jullien

Dans une première partie, l'A. présente Dâdîsh"', moine de langue syriaque et célèbre écrivain spirituel sur la vie monastique. Les différents manuscrits utilisés pour l'édition sont recensés. Suit une introduction (pp. 29-43) sur la notion de quiétude, et sur la thématique chère à Dâdîsh"“' de la conduite en cellule de l'hésychaste. En seconde partie est publiée l'édition critique du texte syriaque des cinq traités, suivie pour finir de la traduction en espagnol. Un index onomastique et toponymique clôt cette étude.

\section{INDEX}

Thèmes : 6.3. Autres religions

\section{AUTEURS}

FLORENCE JULLIEN

EPHE 